(6)

OPEN ACCESS
Department of Neurosurgery, Umberto I General Hospital, Ancona, italy, Italy

Correspondence to Dr Mauro Dobran dobran@libero.it

Accepted 19 June 2017
CrossMark

\section{To cite: Dobran $\mathrm{M}$}

Mancini F, Nasi D, et al. BMJ Case Rep Published Online First: [please include Day Month Year]. doi:10.1136/ bcr-2017-220792

\title{
A case of deep infection after instrumentation in dorsal spinal surgery: the management with antibiotics and negative wound pressure without removal of fixation
}

\author{
Mauro Dobran, Fabrizio Mancini, Davide Nasi, Massimo Scerrati
}

\section{SUMMARY}

Until today the role of spinal instrumentation in the presence of a wound infection has been widely discussed and recently many authors leave the hardware in place with appropriate antibiotic therapy. This is a case of a 65-year-old woman suffering from degenerative scoliosis and osteoporotic multiple vertebral collapses treated with posterior dorsolumbar stabilisation with screws and rods. Four months later, skin necrosis and infection appeared in the cranial wound with exposure of the rods. A surgical procedure of debridement of the infected tissue and package with a myocutaneous trapezius muscle flap was performed. One week after surgery, negative pressure wound therapy was started on the residual skin defect. The wound healed after 2 months. The aim of this case report is to focus on the utility of this method even in the case of hardware exposure and infection. This may help avoid removing instrumentation and creating instability.

\section{BACKGROUND}

Surgical site infection after posterior spinal stabilisation is a serious complication. In some studies, the incidence of site infection after spinal surgery ranges from $0.7 \%$ to $12 \% .^{1-3}$ The removal of hardware is associated with certain complications such as pseudoarthrosis and poor prognosis. A new surgical procedure of stabilisation will be made no earlier than 4/6 months from infection, with risk of complications associated with prolonged immobility. To date, however, there are no clear predictors whether
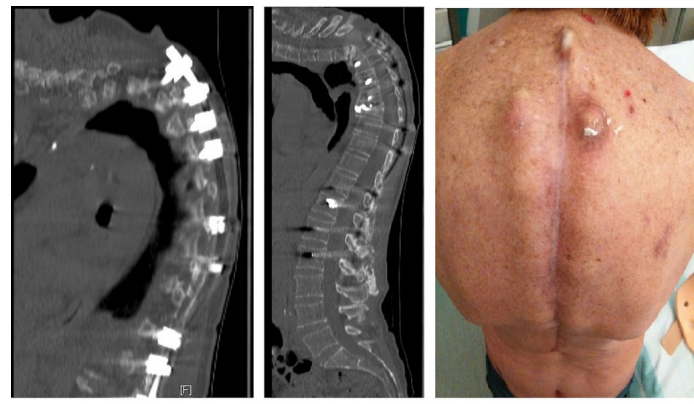

Figure 1 Patient came to our attention with severe kyphosis and evident spinal instrumentation at the subcutaneous level.

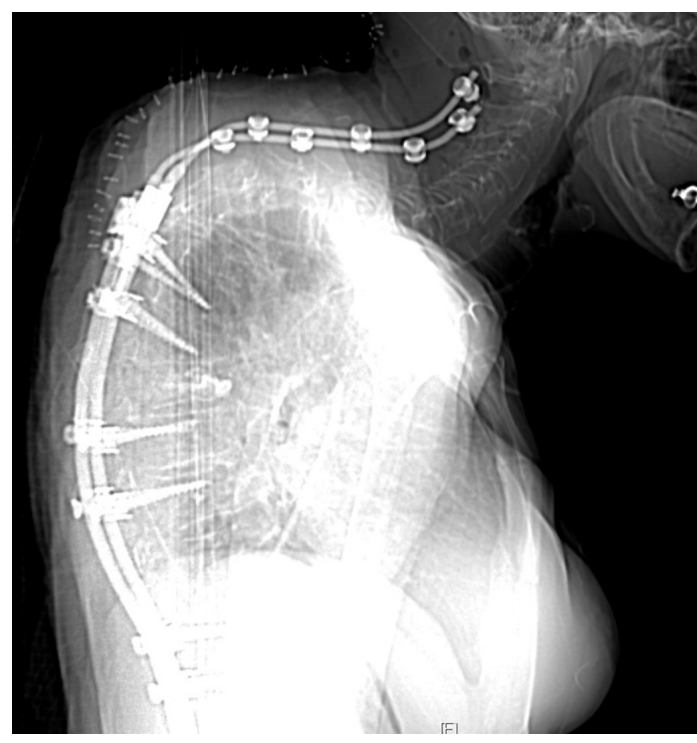

Figure 2 Extension of stabilisation to the cervical level.

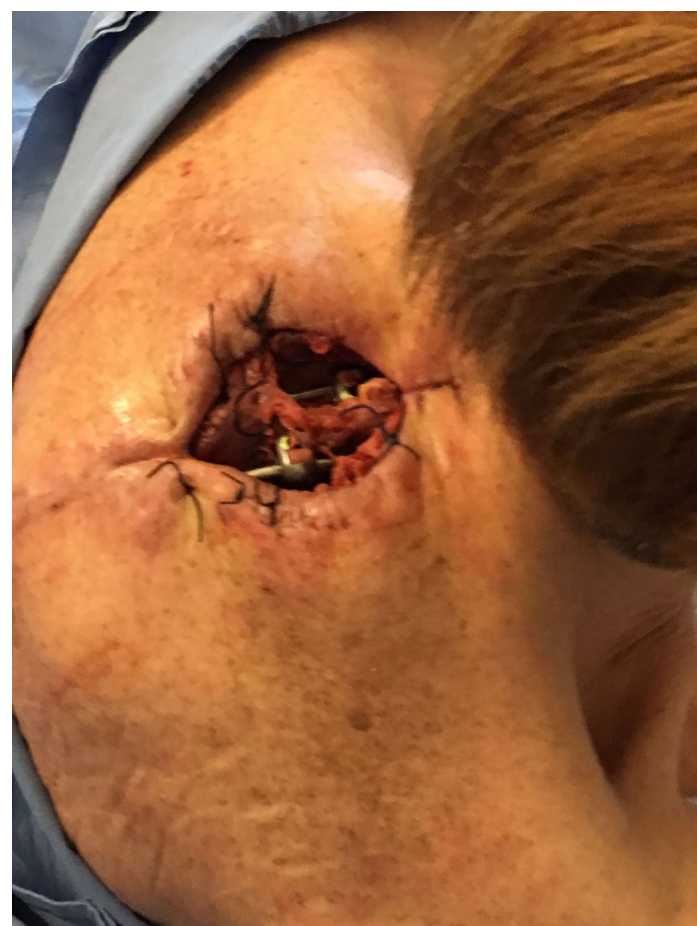

Figure 3 Wound dehiscence after extension of stabilisation to the cervical level. 


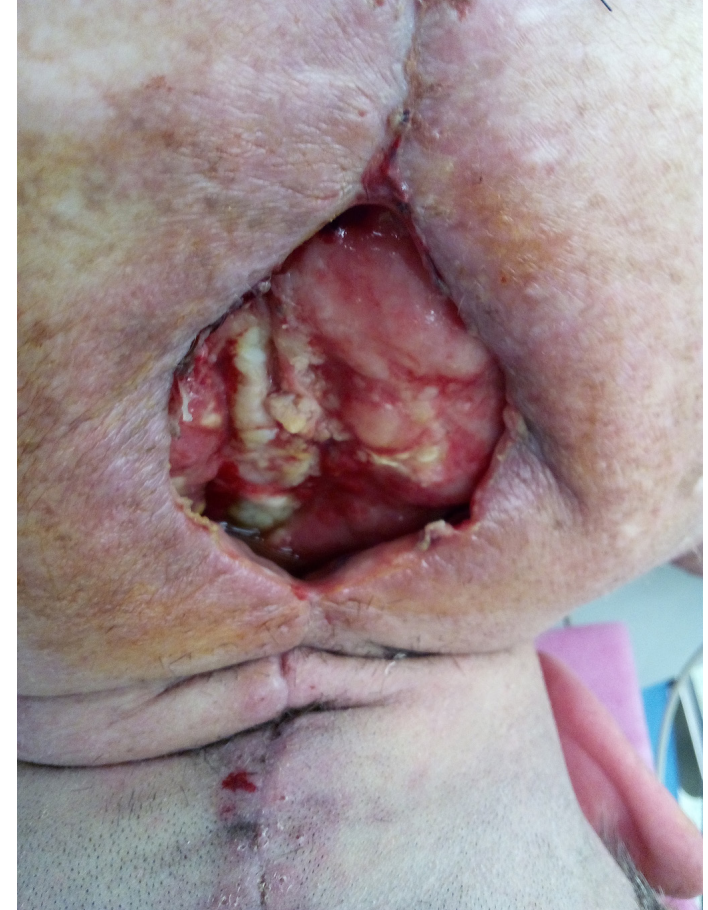

Figure 4 Wound dehiscence after the second surgical procedure of cervical instrumentation removal.

we can safely set a new stabilisation. ${ }^{4}$ In infected wounds, titanium and stainless steel tend to act as substrates for bacterial adherence and biofilm formation, thereby reducing antibiotic penetration. ${ }^{5}$ Compared with stainless steel, titanium is less prone to colonisation, ${ }^{67}$ therefore, today it is the material of choice for spinal stabilisation.

Negative pressure wound therapy (vacuum-assisted closure (VAC)) for the treatment of infected skin wounds was popularised

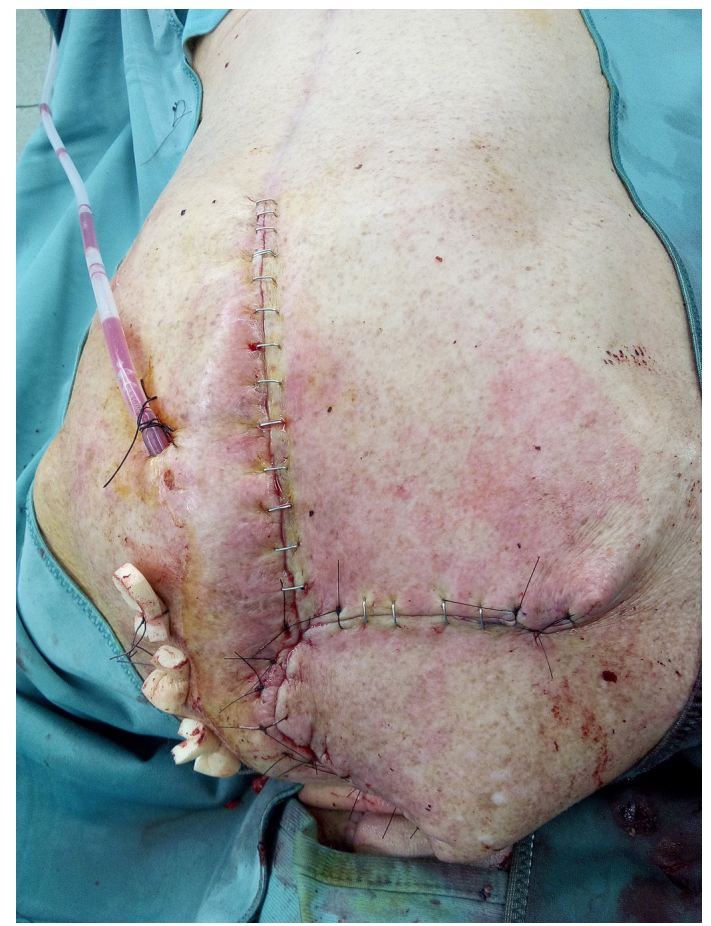

Figure 5 Revision of the surgical wound with a myocutaneous trapezius muscle flap.

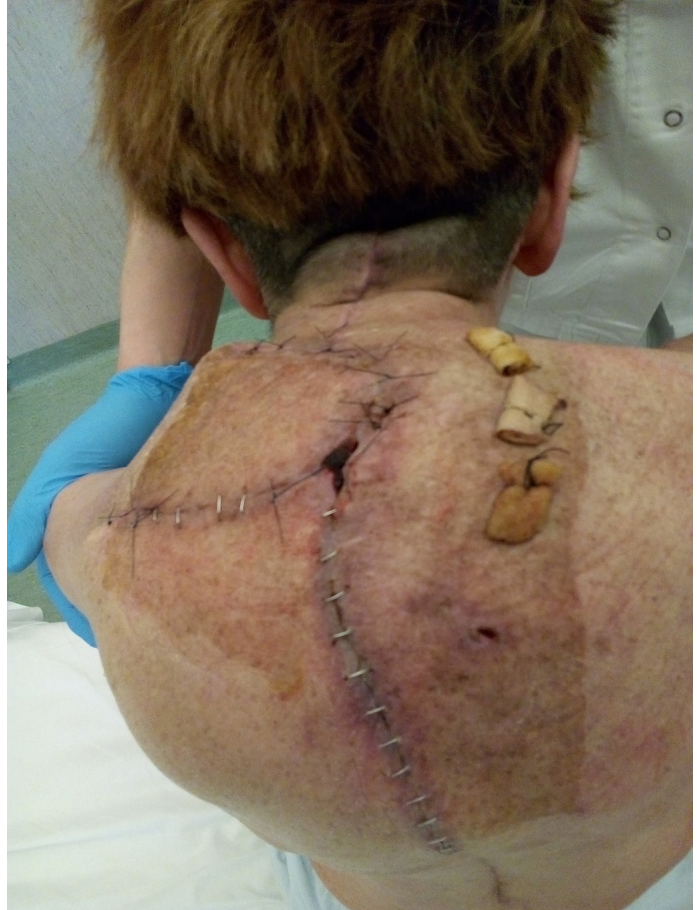

Figure 6 Little wound dehiscence after surgical wound revision.

by Argenta and Morykwas with good results in the USA. ${ }^{8}$ Today this technique is commonly used by plastic surgeons to treat chronic wounds or other problematic acute wounds. In spinal surgery, the use of the stabilisation devices may be difficult in patients with thin skin or cachexia and the exposure of prosthesis cause devastating complications in such patients. The possibility to use a non-invasive therapy allowing wound healing without prosthesis removal is a big advantage. The removal of spinal stabilisation can be carried out if the wound pressure therapy does not produce improvement in a reasonable lapse of time (1 or 2 months), or when the local infection worsens over time. The first therapeutic act is, however, namely the surgical cleaning of the infected wound and then application of VAC and targeted antibiotic therapy.

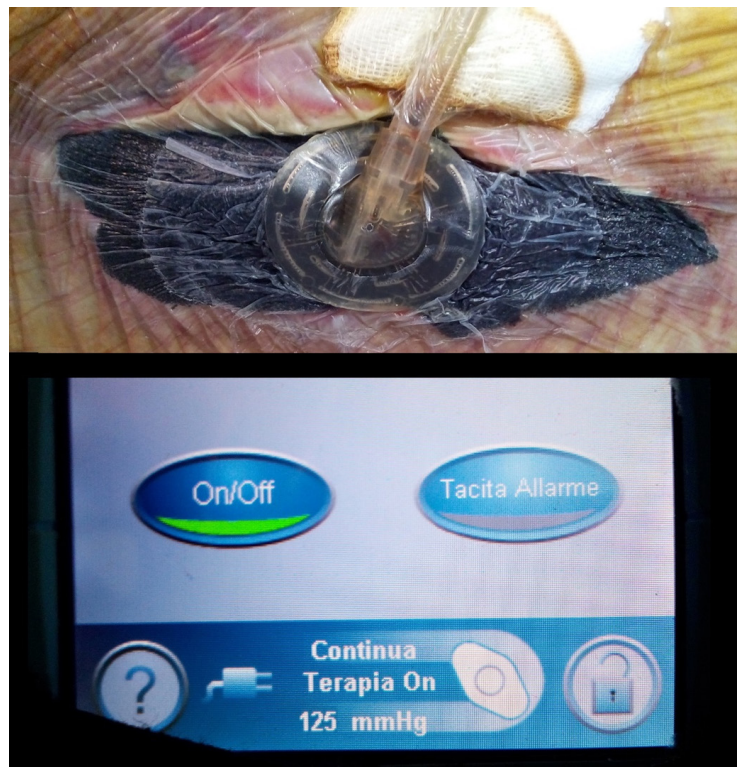

Figure 7 Vacuum-assisted closure. 


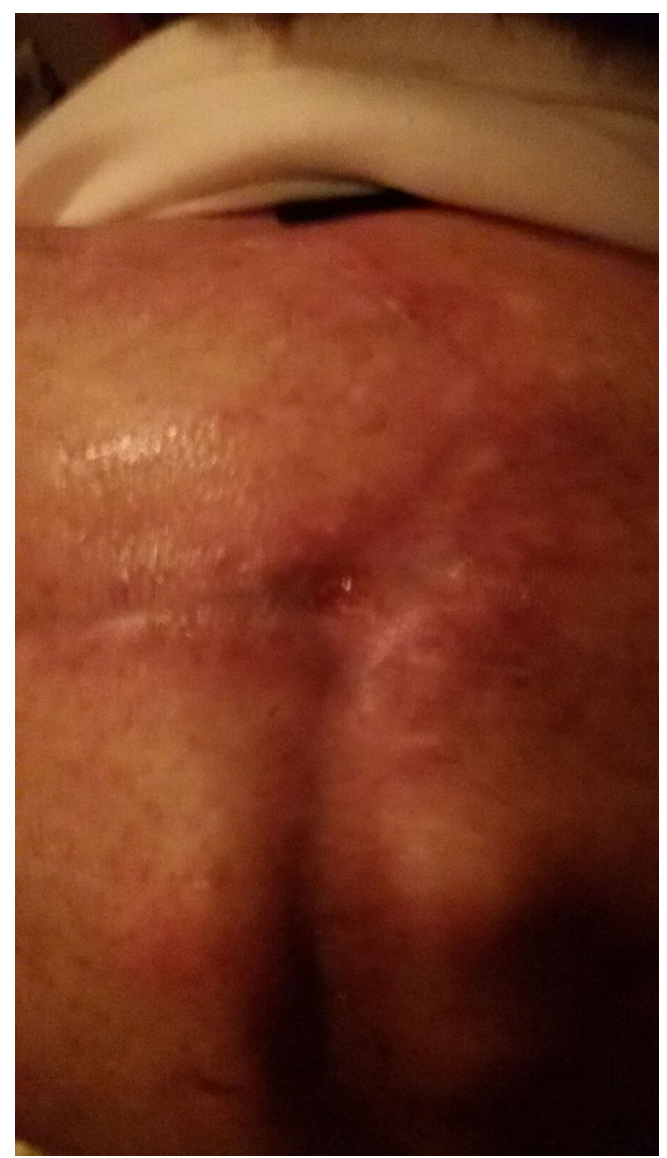

Figure 8 Wound closure after 2 months of VAC. VAC, vacuum-assisted closure.

\section{CASE PRESENTATION}

This is a case of a 62-year-old woman with a history of osteoporotic multiple vertebral collapses treated with posterior stabilisation with screws and rods from D3 to D12. She was a very thin patient with almost no subcutaneous fat (figure 1). The second operation was an extension of stabilisation to the cervical level (figure 2). Due to the dehiscence of the cranial end of the wound, cervical instrumentation was removed and the dorsal rods were cut at T4-T5 level and bilateral T3-T4 screws were removed as well (figure 3). On removal of stitches 12 days from surgery, the wound reopened (figure 4). The cultural examination of the wound was found to be positive for Staphylococcus aureus.

\section{TREATMENT}

After 2 weeks of antibiotic therapy (piperacillin sodium/tazobactam sodium $500 \mathrm{mg} /$ two times a day), a revision of the surgical wound was performed using a myocutaneous trapezius muscle flap (figure 5). The remainder skin discontinuity (figure 6) of $3 \mathrm{~cm}$ wide was treated with VAC and antibiotics (after 10 days of vancomycin $500 \mathrm{mg}$ four times a day, therapy was continued with piperacillin sodium/tazobactam $500 \mathrm{mg}$ two times a day for the whole hospitalisation period) for 2 months with complete recovery (figure 7 ). The wound was covered with one layer of non-adherent dressing, and the sponge was applied with plaster. To ensure the dressing sealing, a pressure bandage was applied to the wound along with manual compression in order to get rid of any air space. The pressure was lowered to $125 \mathrm{~mm} \mathrm{Hg}$. The sponge was replaced every 3-4 days. The patient was positioned in lateral position when recumbent in her bed.

\section{OUTCOME AND FOLLOW-UP}

Resolution of the presenting clinical symptoms and signs was achieved immediately after the operation of a myocutaneous trapezius muscle flap. The recovery of residual skin defect was accomplished after 2 months of VAC therapy (figure 8). During the VAC therapy, antibiotics were continued.

\section{DISCUSSION}

Postoperative spinal infection occurs in 1\%-5\% of patients undergoing spine surgery. ${ }^{9-11}$ The risk is highest in patients undergoing posterior approaches, such as lumbar surgery, spinal augmented procedures or long surgical times. Furthermore, infection of spinal hardware may be possible in the case of obesity, diabetes and alcohol abuse. ${ }^{12}$ In patients with spinal wound infection, it may be very difficult to choose the right medical or surgical treatment. Reopening the wound by means of a new surgical approach may be very troublesome when stabilisation has been implanted. Today titanium instrumentation grants an advantage: titanium alloy is less prone to colonisation than stainless steel. Titanium is handy and widely used in spinal stabilisation particularly in traumatic pathologies of the column. ${ }^{13}{ }^{14}$ In vitro studies suggest that biofilm can blocks antibiotics, phagocytes and other humoral immune responders making infection relatively resistant to host-defensive mechanisms and antibiotics. ${ }^{67}$ As the removal of the spinal hardware in infected patients causes postoperative instability, it is useful to identify a non-surgical procedure that allows treating surgical infections without removing the hardware. At the same time, it is necessary to facilitate the closure of the surgical wound too. Until today multiple techniques have been used helping for delayed wound closure. ${ }^{15} 16$ Negative pressure wound therapy (VAC) has been widely used for many years to treat complicated wounds and in case of failure of a surgical procedure. In the present case VAC therapy, also in the presence of a wound infection, allowed the healing of the wound without removing the hardware. This is in line with the current trend to maintain hardware in infected patients too. ${ }^{17}$ Moreover, in recent years, direct spinal fixation following the debridement of the tuberculous spondylitis or pyogenic discitis has been conducted and fixation combined with aggressive antibiotic therapy resulted in healing of many spinal infections. The VAC therapy in infected wound may be very useful as a significant increase of antibiotic concentration in the infected tissue treated by VAC therapy is demonstrated. ${ }^{18} 19$ In patients with infected wounds, it is necessary to maintain antibiotics until the wound heals completely and negative wound culture is obtained. Posterior screws fixation with titanium in the case of infected wound is the material of choice. The first option in case of wound infection and exposure of the hardware is debridement of the wound, primary closure and antibiotic therapy. In the case of incomplete wound

\section{Learning points}

- Negative pressure wound therapy may be useful to treat skin defect especially when wound infection is present, even in the case of spinal hardware exposure.

- By leaving the hardware in place many complications such as pseudoarthrosis, instability or kyphosis with chronic pain and finally inability to work can be avoided.

- The removal of spinal instrumentation might be necessary if vacuum-assisted closure therapy does not produce a satisfactory improvement in a reasonable lapse of time. 
closure or failure of surgical therapy, the use of negative wound pressure (VAC) may allow the final closure of the wound even in spinal surgery with vertebral stabilisation. Only in the case of abscess or resistant infection, a new surgical procedure with removal of the spinal fixation may be necessary.

Contributors MD: design of the work; FM: drafting; DN: revising and MS: final approving.

Competing interests None declared.

\section{Patient consent Obtained.}

Provenance and peer review Not commissioned; externally peer reviewed.

Open Access This is an Open Access article distributed in accordance with the Creative Commons Attribution Non Commercial (CC BY-NC 4.0) license, which permits others to distribute, remix, adapt, build upon this work non-commercially, and license their derivative works on different terms, provided the original work is properly cited and the use is non-commercial. See: http://creativecommons.org/ licenses/by-nc/4.0/

(c) BMJ Publishing Group Ltd (unless otherwise stated in the text of the article) 2017. All rights reserved. No commercial use is permitted unless otherwise expressly granted.

\section{REFERENCES}

1 Mehta Al, Babu R, Karikari IO, et al. 2012 Young Investigator Award winner: The distribution of body mass as a significant risk factor for lumbar spinal fusion postoperative infections. Spine 2012;37:1652-6.

2 Lee MJ, Cizik AM, Hamilton D, et al. Predicting surgical site infection after spine surgery: a validated model using a prospective surgical registry. Spine J 2014;14:2112-7.

3 Tao W, Hui W, Da-long Y, et al. Factors predicting surgical site infection after posterior lumbar surgery. Medicine 2017;96:5.

4 Hiroyuki T, Takao S, Hideki K, et al. Risk factors for unvaiodable removal of instrumentation after surgical site infection of spine surgery. Medicine 2016;95:43.
5 Sundararaj GD, Amritanand R, Venkatesh $\mathrm{K}$, et al. The use of titanium mesh cages in the reconstruction of anterior column defects in active spinal infections: can we rest the crest? Asian Spine J 2011;5:155-61.

6 Sundararaj GD, Babu N, Amritanand R, et al. Treatment of haematogenous pyogenic vertebral osteomyelitis by single-stage anterior debridement, grafting of the defect and posterior instrumentation. J Bone Joint Surg Br 2007;89:1201-5.

7 Christodoulou AG, Givissis P, Karataglis D, et al. Treatment of tuberculous spondylitis with anterior stabilization and titanium cage. Clin Orthop Relat Res 2006:444:60-5.

8 Argenta LC, Morykwas MJ. Vacuum-assisted closure: a new method for wound control and treatment: clinical experience. Ann Plast Surg 1997;38:563-77.

9 Bible JE, Biswas D, Devin CJ, et al. Postoperative infections of the spine. Am J Orthop 2011;40:E264-71.

10 Gerometta A, Rodriguez Olaverri JC, Bitan F, et al. Infections in spinal instrumentation. Int Orthop 2012;36:457-64.

11 Meredith DS, Kepler CK, Huang RC, et al. Postoperative infections of the lumbar spine: presentation and management. Int Orthop 2012;36:439-44.

12 Maragakis LL, Cosgrove SE, Martinez EA, et al. Intraoperative fraction of inspired oxygen is a modifiable risk factor for surgical site infection after spinal surgery. Anesthesiology 2009;110:556-62.

13 Dobran M, lacoangeli M, Di Somma LG, et al. Neurological outcome in a series of 58 patients operated for traumatic thoracolumbar spinal cord injuries. Surg Neurol Int 2014;5:S329-32.

14 Dobran M, Nasi D, Brunozzi D, et al. Treatment of unstable thoracolumbar junction fractures: short-segment pedicle fixation with inclusion of the fracture level versus long-segment instrumentation. Acta Neurochir 2016;158:1883-9.

15 Dodenhoff RM, Howell GE. The shoelace technique for wound closure in open fractures: report of early experience. Injury 1997;28:593-5.

16 Kafie FE, Tessier DJ, Williams RA, et al. Serial abdominal closure technique (the "SAC" procedure): a novel method for delayed closure of the abdominal wall. Am Surg 2003;69:102-5.

17 Dobran M, lacoangeli M, Nasi D, et al. Posterior Titanium Screw fixation without Debridement of infected tissue for the treatment of Thoracolumbar Spontaneous Pyogenic Spondylodiscitis. Asian Spine J 2016;10:465-71.

18 Lo Torto F, Ruggiero M, Parisi P, et al. The effectiveness of negative pressure therapy on infected wounds: preliminary results. Int Wound J 2017.

19 El-Sabbagh AH. Negative pressure wound therapy: an update. Chin J Traumatol 2017:20:103-7.

Copyright 2017 BMJ Publishing Group. All rights reserved. For permission to reuse any of this content visit http://group.bmj.com/group/rights-licensing/permissions.

BMJ Case Report Fellows may re-use this article for personal use and teaching without any further permission.

Become a Fellow of BMJ Case Reports today and you can:

- Submit as many cases as you like

- Enjoy fast sympathetic peer review and rapid publication of accepted articles

- Access all the published articles

- Re-use any of the published material for personal use and teaching without further permission

For information on Institutional Fellowships contact consortiasales@bmjgroup.com

Visit casereports.bmj.com for more articles like this and to become a Fellow 